\title{
Natural flowering on pineapple: inhibition by growth regulators
}

\author{
Getulio Augusto Pinto da Cunha ${ }^{a *}$, José Tarciso Alves Costa ${ }^{b}$, Domingo Haroldo Reinhardt ${ }^{a}$
}

a Embrapa Cassava and Fruit Crops, PO Box 007,

44.380-000, Cruz das Almas, BA, Brazil

b UFC, PO Box 6012, 60.451-970, Fortaleza, CE, Brazil

${ }^{*}$ Correspondence and reprints

Received March 31, 2002 Accepted September 26, 2002

Fruits, 2003, vol. 58, p. 27-37 (C) 2003 Cirad/EDP Sciences All rights reserved DOI: 10.1051/fruits:2002034

RESUMEN ESPAÑoL, p. 37

\section{Natural flowering in pineapple: inhibition by growth regulators.}

Abstract - Introduction. Natural flowering is an obstacle for the management of pineapple production. This phenomenon is at the origin of considerable and increasing fruit losses on an international scale. The objective of this work was to determine, at various times of the year, the role of substances inhibiting the vegetative growth of the plant to prevent, reduce or delay the natural pineapple flowering of the variety 'Perola', most planted in Brazil. Materials and methods. Two trials were conducted in the experimental field in Cruz das Almas, Bahia, Brasil, during the years 1996 to 1999. Various growth substances were tested at various concentrations: propionic acid 2-(3-chlorophenoxy) (ACP) at (45, 90 and 120$) \mathrm{mg} \cdot \mathrm{L}^{-1}$, paclobutrazole (PBZ) at $(77.4,155.8$ and 320$) \mathrm{mg} \cdot \mathrm{L}^{-1}$ mepiquat chlorure (MC) at (60 and 120$) \mathrm{mg} \cdot \mathrm{L}^{-1}$, gibberelic acid $\left(\mathrm{GA}_{3}\right)$ at $(30$ and 60$) \mathrm{mg} \cdot \mathrm{L}^{-1}$, tebuconazole (TBZ) at $(60$ and 120$) \mathrm{mg} \cdot \mathrm{L}^{-1}$ and propaconazole (PPZ) at $120 \mathrm{mg} \cdot \mathrm{L}^{-1}$. The treatments were applied onto two, three or four split applications, every 15 days, from 7:00 to 9:00 a.m. and from April to July (the critical period for natural flowering in the region). Results and discussion. The results obtained show that $\mathrm{ACP}$ and PBZ are capable of inhibiting, reducing and delaying the natural flowering of pineapple with the concentrations of $(90$ to 240$) \mathrm{mg} \cdot \mathrm{L}^{-1}$. The best results were obtained when the growth regulators were applied during April and May. The other products did not have an effect on the natural flowering of pineapple. Conclusion. The variation observed in the effects and efficiencies of the growth regulators used indicates the necessity of validating the best treatments under different environmental and cultural conditions. The selected growth regulators can be a valuable tool for physiological studies on the mechanisms of flowering initiation in pineapple.

\section{Brazil / Ananas comosus / flowering / precocity / growth inhibitors / triazoles}

Floraison naturelle chez l'ananas : inhibition par les régulateurs de croissance.

Résumé - Introduction. La floraison naturelle est un obstacle pour la gestion de la production d'ananas. Ce phénomène est à l'origine de pertes considérables et croissantes à l'échelle internationale. L'objectif de ce travail a été de déterminer, à différentes époques de l'année, le rôle de substances inhibant la croissance végétative de la plante pour empêcher, réduire ou retarder la floraison naturelle d'ananas de la variété 'Perola' la plus exploitée au Brésil. Matériel et méthodes. Deux essais ont été suivis en parcelle expérimentale à Cruz das Almas, Bahia, Brésil, pendant les années 1996 à 1999. Diverses substances de croissance ont été testées et cela à différentes concentrations : l'acide 2-(3-chlorophenoxy) propionique $(\mathrm{ACP})$ à $(45,90$ et 120$) \mathrm{mg} \cdot \mathrm{L}^{-1}$, le paclobutrazole (PBZ) à $(77,4,155,8$ et 320$) \mathrm{mg} \cdot \mathrm{L}^{-1}$, le chlorure de mepiquat $(\mathrm{CM})$ à (60 et 120$) \mathrm{mg} \cdot \mathrm{L}^{-1}$, l'acide gibberelic $\left(\mathrm{GA}_{3}\right)$ à $(30$ et 60$) \mathrm{mg} \cdot \mathrm{L}^{-1}$, le tebuconazole (TBZ) à (60 et 120$) \mathrm{mg} \cdot \mathrm{L}^{-1}$ et le propaconazole (PPZ) à $120 \mathrm{mg} \cdot \mathrm{L}^{-1}$. Les traitements ont été appliqués en deux, trois ou quatre doses égales, tous les 15 jours, de 7:00 à 9:00 h du matin et d'avril à juillet (période critique pour les floraisons naturelles dans la région d'essai). Résultats et discussion. Les résultats obtenus ont montré que l'ACP et le PBZ sont capables d'inhiber, réduire et retarder la floraison naturelle d'ananas aux concentrations comprises entre (90 et 240) $\mathrm{mg} \cdot \mathrm{L}^{-1}$. Les meilleurs résultats ont été obtenus quand les régulateurs de croissance étaient appliqués pendant les mois d'avril et de mai. Les autres produits testés n'ont pas eu d'effets sur la floraison naturelle de l'ananas. Conclusion. Les effets et l'efficacité variables des régulateurs de croissance employés conduisent à devoir adapter les traitements aux différentes conditions environnementales et culturelles. Les régulateurs de croissance ACP et PBZ pourraient être utiles pour des études physiologiques sur les mécanismes de l'initiation florale chez l'ananas.

Brésil / Ananas comosus / floraison / précocité / inhibiteur de croissance / triazole 


\section{Introduction}

Pineapple has always been an important economic crop due to its fruit characteristics. This plant is very appreciated all over the world, where it is cultivated in more than 60 countries. In Brazil, where it is the third most planted tropical fruit, it also represents a good option for cultivation in the semi-arid and "cerrados" (savanna) regions In that country, 'Perola' (Ananas comosus) is the most planted cultivar.

Flowering in pineapple can occur naturally, related to environmental factors, or artificially when induced with chemical substances, in general, growth regulators. The commercial cultivation of the pineapple crop results from the fact that flowering in this plant can be controlled, and thus, harvesting can be scheduled according to the desired season of production (better fruit prices), or carried out throughout the year.

Natural flowering in pineapple causes serious problems, mainly when precocious, in all producing areas around the world, and it is becoming very frequent. Natural flowering makes pineapple management difficult because assorted fruits are produced and harvest dates cannot be scheduled. That is the reason for controlling or minimizing its negative effects on the pineapple plant and fruit.

The premises of this work are that precocious pineapple flowering can be avoided or delayed, if (1) the vegetative growth of the plant is reduced in such a way that it will not be able to flower at the time when the weather conditions become favorable to natural flowering; (2) the vegetative growth rate of the plant is increased due to the use of some production factors, such as nitrogen fertilization and irrigation; and (3) the biosynthesis and action of ethylene in the plant are inhibited or blocked, with the use of some chemical substances. The growth regulators used in this work were selected because of their general inhibiting effects on the vegetative growth of the plants, and also because they have already been tested in previous trials, related to natural flowering control.
The objective of this study was to determine the role of some substances which inhibit the vegetative growth of the plant, applied in different seasons of the year, on the inhibition, reduction or delay of natural flowering on pineapple Perola.

\section{Materials and methods}

Two experiments were carried out in the experimental field of Embrapa Cassava and Tropical Fruit Crops, at Cruz das Almas $\left(12^{\circ}\right.$ 40" 30' S; 30 06" 23' W; $225 \mathrm{~m}$ altitude), BA, Brazil, from 1996 to 1999. The mean annual climatic conditions of the area are: rainfall, $1224 \mathrm{~mm}$; temperature, $23.8^{\circ} \mathrm{C}$ with minimal temperature of $17.5^{\circ} \mathrm{C}$ in June, and $18.9^{\circ} \mathrm{C}$ in August, the coldest months; air relative humidity, $80 \%$; minimal solar radiation in June with $140 \mathrm{~h} \cdot \mathrm{mo}^{-1} /$ $4.5 \mathrm{~h} \cdot \mathrm{d}^{-1}$, and in August with $170 \mathrm{~h} \cdot \mathrm{mo}^{-1} /$ $5.5 \mathrm{~h} \cdot \mathrm{d}^{-1}$.

The planting material used in all experiments was slips [(250 to 350) g] of the $\mathrm{cv}$. Perola. The growth regulator solutions were sprayed on the whole plant $(50 \mathrm{~mL})$ with a manual sprayer, concentrated mainly on the center of the leaf rosette. Treatments were applied as equal split concentrations, fortnightly (early in the morning) from April to July (the most critical period for natural flowering in the region), as follows.

For the experiment I, planted in July 1996, the growth substance applications (table Ia) began in the middle of each month corresponding to the treatments (May, June and July 1997), when the plants were (10 to 12 ) months old. The experimental design was in randomized blocks [factorial $(4 \times 2)+1$ ], with five replications, and 30 useful plants per plot of 45 plants.

For the experiment II, planted in September 1997, the applications (table Ib) began in April 17, 1998, for the first season studied and in May 19, 1998, for the second season, when the plants were ( 8 and 9) months old. The experimental design was in randomized blocks, with five replications, and 40 useful plants per plot of 72 plants. 
Table I.

Experiments conducted with growth substance applications to control pineapple flowering from 1996 to 1999. The treatments (50 mL·plant ${ }^{-1}$ ) were applied as two to four equal split applications, fortnightly (7-9 a.m.) from April to July, which is the critical period for natural flowering in the region (Cruz das Almas, Bahia, Brazil).

(a) Experiment I

\begin{tabular}{|c|c|c|c|c|c|c|c|}
\hline \multirow[t]{2}{*}{ Planting time } & \multirow[t]{2}{*}{$\begin{array}{l}\text { Time of applications } \\
\text { (1997) }\end{array}$} & \multirow[t]{2}{*}{$\begin{array}{l}\text { Number of } \\
\text { applications }\end{array}$} & \multicolumn{5}{|c|}{$\begin{array}{c}\text { Dose applied } \\
\text { (active ingredient) }\end{array}$} \\
\hline & & & $\mathrm{ACP}^{1}$ & Paclobutrazole & $\begin{array}{l}\text { Gibberellic } \\
\text { acid }\end{array}$ & $\begin{array}{l}\text { Mepiquat } \\
\text { chloride }\end{array}$ & $\begin{array}{l}\text { Water } \\
\text { (control) }\end{array}$ \\
\hline \multirow[t]{2}{*}{ July 1996} & May, June and July & 3 & $15 \mathrm{mg} \cdot \mathrm{L}^{-1}$ & $25,8 \mathrm{mg} \cdot \mathrm{L}^{-1}$ & $10 \mathrm{mg} \cdot \mathrm{L}^{-1}$ & $20 \mathrm{mg} \cdot \mathrm{L}^{-1}$ & $50 \mathrm{~mL} \cdot$ plant $^{-1}$ \\
\hline & 1997 & 3 & $30 \mathrm{mg} \cdot \mathrm{L}^{-1}$ & $51,6 \mathrm{mg} \cdot \mathrm{L}^{-1}$ & $20 \mathrm{mg} \cdot \mathrm{L}^{-1}$ & $40 \mathrm{mg} \cdot \mathrm{L}^{-1}$ & - \\
\hline \multicolumn{8}{|c|}{ (b) Experiment II } \\
\hline \multirow[t]{2}{*}{ Planting time } & $\begin{array}{l}\text { Time of applications } \\
\text { (active ingredient) }\end{array}$ & $\begin{array}{l}\text { Number of } \\
\text { applications }\end{array}$ & \multicolumn{5}{|c|}{$\begin{array}{c}\text { Dose applied } \\
\text { (active ingredient) }\end{array}$} \\
\hline & & & $\mathrm{ACP}^{1}$ & Paclobutrazole & Tebuconazole & Propaconazole & $\begin{array}{l}\text { Water } \\
\text { (control) }\end{array}$ \\
\hline September & April/ May1998 & 2 & $45 \mathrm{mg} \cdot \mathrm{L}^{-1}$ & $120 \mathrm{mg} \cdot \mathrm{L}^{-1}$ & - & - & - \\
\hline \multirow{3}{*}{1997} & May/June 1999 & 3 & $30 \mathrm{mg} \cdot \mathrm{L}^{-1}$ & $80 \mathrm{mg} \cdot \mathrm{L}^{-1}$ & $20 \mathrm{mg} \cdot \mathrm{L}^{-1}$ & $40 \mathrm{mg} \cdot \mathrm{L}^{-1}$ & - \\
\hline & & 3 & - & - & $40 \mathrm{mg} \cdot \mathrm{L}^{-1}$ & - & - \\
\hline & & 4 & $30 \mathrm{mg} \cdot \mathrm{L}^{-1}$ & $80 \mathrm{mg} \cdot \mathrm{L}^{-1}$ & - & - & $50 \mathrm{~mL} \cdot$ plant $^{-1}$ \\
\hline
\end{tabular}

${ }^{1}$ ACP: 2-(3-chlorophenoxy) propionic acid.

The data on flowering percentages was based on the number of plants with inflorescences counted every week, from 40 days after the first application of the treatments, over 5 months. The results were analyzed by the F test, with the average comparison by Tukey's and ScottKnot's tests.

\section{Results and discussion}

\subsection{The $1996 / 1997$ experiment}

The results of the 1996/1997 experiment (table II) showed that there were two distinct groups among the treatments: (a) when applied in May and in the higher concentrations of $(90,154.8$ and 60$) \mathrm{mg} \cdot \mathrm{L}^{-1}$, respectively, the propionic acid 2-(3-chlorophenoxy) (ACP), paclobutrazole (PBZ) and gibberelic acid $\left(\mathrm{GA}_{3}\right)$ treatments had a significant inhibition effect on plant flowering, giving rise to $14.3 \%$ to $32.9 \%$ of flowering, while there was $45.8 \%$ of flowering for the control; (b) as reported in other work [1], the two mepiquat chloride (CM) concentrations in the treatments $(37.6 \%$ and $42.5 \%$ of flowering), and the $30 \mathrm{mg} \cdot \mathrm{L}^{-1}$ $\mathrm{GA}_{3}$ treatment (40.5\% of flowering) did not differ from the control and formed another group.

$\mathrm{GA}_{3}$ probably influences the distribution of assimilates between the stem apex and the flowers, favoring the former, and it seems to be able to substitute for some specific weather conditions, which control flower formation and improve fruit quality [2]. A low $\mathrm{GA}_{3}$ concentration did not delay flowering in Aechmea [3], which was also observed in the pineapple crop $[4,5]$. However, according to the latter authors, the $\mathrm{GA}_{3}$, despite increasing the 
Table II.

Effect of growth regulators on the control of natural flowering (\%) of pineapple, cv. Perola, according to three seasons of application. Average for three evaluation dates (Cruz das Almas, Bahia, Brazil, planting July 1996).

\begin{tabular}{|c|c|c|c|c|}
\hline \multirow[t]{2}{*}{ Treatment } & \multirow{2}{*}{$\begin{array}{l}\text { Dose } \\
\left(\mathrm{mg} \cdot \mathrm{L}^{-1}\right)\end{array}$} & \multicolumn{3}{|c|}{ Natural flowering (\%) } \\
\hline & & $\begin{array}{l}\text { Application } \\
\text { in May } 1997\end{array}$ & $\begin{array}{l}\text { Application } \\
\text { in June } 1997\end{array}$ & $\begin{array}{l}\text { Application } \\
\text { in July } 1997\end{array}$ \\
\hline Control (water) & $50 \mathrm{~mL} \cdot \mathrm{plant}^{-1}$ & $45.8 \mathrm{a}$ & 40.7 & $50.5 \mathrm{a}$ \\
\hline $\mathrm{ACP}^{1}$ & $\begin{array}{l}45 \\
90\end{array}$ & $\begin{array}{l}28.7 b \\
14.3 c\end{array}$ & $\begin{array}{l}42.1 \\
35.4\end{array}$ & $\begin{array}{l}51.8 \mathrm{a} \\
38.5 \mathrm{~b}\end{array}$ \\
\hline Paclobutrazole & $\begin{array}{l}77,4 \\
154,8\end{array}$ & $\begin{array}{l}30.5 b \\
20.1 c\end{array}$ & $\begin{array}{l}47.6 \\
37.8\end{array}$ & $\begin{array}{l}38.9 \mathrm{~b} \\
52.9 \mathrm{a}\end{array}$ \\
\hline Gibberellic acid & $\begin{array}{l}30 \\
60\end{array}$ & $\begin{array}{l}40.5 \mathrm{a} \\
32.9 \mathrm{~b}\end{array}$ & $\begin{array}{l}52.4 \\
47.3\end{array}$ & $\begin{array}{l}50.5 \mathrm{a} \\
52.7 \mathrm{a}\end{array}$ \\
\hline Mepiquat chloride & $\begin{array}{l}60 \\
120\end{array}$ & $\begin{array}{l}37.6 \mathrm{a} \\
42.5 \mathrm{a}\end{array}$ & $\begin{array}{l}46.7 \\
43.1\end{array}$ & $\begin{array}{l}55.3 \mathrm{a} \\
47.1 \mathrm{a}\end{array}$ \\
\hline General average & - & 32.5 & 43.7 & 48.7 \\
\hline Test F & - & ** & ns & ** \\
\hline $\begin{array}{l}\text { Coefficient of } \\
\text { variation }(\%)\end{array}$ & - & 15.26 & 27.94 & 22.08 \\
\hline
\end{tabular}

peduncle length, reduced the pineapple inflorescence size, which can be an indication of its involvement in flower development. In Hawaii, all the plants which had been previously treated with $\mathrm{GA}_{3}$ were induced to flower equally by the climatic factors and by ethephon, as well as the control treatment [6].

The decrease in the efficiency of the inhibition treatments during June and July (table II) may be the result of a reduction in the plant growth rate, which will be discussed later, in association with the weather conditions, favorable to flower initiation, to the detriment of the growth regulator performance. According to the results, June and July showed to be too late a season for the application of growth regulators in order to inhibit natural flowering in the pineapple crop, in the region of Cruz das Almas, BA, because they present the shortest photoperiod (11.4 h), a low irradiance $\left[(140\right.$ to 170$) \mathrm{h} \cdot \mathrm{mo}^{-1}$ and ( 4.5 to 5.5) $\mathrm{h} \cdot \mathrm{day}^{-1}$ and the lowest night temperatures $\left(18-19^{\circ} \mathrm{C}\right)$.

In relation to the seasons of application of the growth regulators, May was the most favorable month for inhibition, since its general average flowering rate was the lowest, $32.5 \%$, in comparison with June, $43.8 \%$, and July, $48.7 \%$ (table III). However, if we consider only the two first evaluations, the rate of inhibition was still higher than in the other months, since flowering reached only $10.3 \%$. In the last observation, the inhibition rates were low, which means that the effects of the growth regulators had decreased.

The majority of the inflorescences emerged during July and August, which is an indication that the floral initiation at the apical meristem, which in general takes 
Table III.

Effect of growth regulators on the control of natural flowering (\%) of pineapple, cv. Perola, according to three seasons of application and three evaluation dates (Cruz das Almas, Bahia, Brazil, planting July 1996).

\begin{tabular}{|c|c|c|c|c|c|c|}
\hline \multirow[t]{2}{*}{ Evaluation date } & \multicolumn{2}{|c|}{$\begin{array}{l}\text { Application } \\
\text { in May } 1997\end{array}$} & \multicolumn{2}{|c|}{$\begin{array}{c}\text { Application } \\
\text { in June } 1997\end{array}$} & \multicolumn{2}{|c|}{$\begin{array}{l}\text { Application } \\
\text { in July } 1997\end{array}$} \\
\hline & Date & Flowering (\%) & Date & Flowering (\%) & Date & Flowering (\%) \\
\hline Initial (A) & June 20 & $0 \mathrm{c}$ & July 15 & $1.1 \mathrm{c}$ & August 13 & $14.6 \mathrm{c}$ \\
\hline Intermediate (B) & August 13 & $20.6 b$ & August 29 & $49.8 \mathrm{~b}$ & September 13 & $61.9 \mathrm{~b}$ \\
\hline Final (C) & November 21 & $76.9 \mathrm{a}$ & November 21 & $80.2 \mathrm{a}$ & November 21 & $69.5 \mathrm{a}$ \\
\hline Test F & - & ** & - & ** & - & ** \\
\hline Average $(A, B, C)$ & - & 32.5 & - & 43.8 & - & 48.7 \\
\hline Average $(A, B)$ & - & 10.3 & - & 25.4 & - & 38.2 \\
\hline
\end{tabular}

place 45 days before the emersion, occurred mainly in June.

The reduction in the inhibition rates observed in all treatments (table III) at the final evaluation (November 21, 1997) could be due to the decrease in the product concentrations inside the plants and, thus, to the increase in the production and/or activity of ethylene, or in the susceptibility/ sensibility o.f the pineapple plant to florigen factors (endogenous and environmental). Similar results were reported in Australia, specifically in relation to ACP [7].

Flowering in the pineapple crop is a result of an interaction between endogenous inhibitors and ethylene level, this being a prerequisite for floral differentiation [8]. These authors suggested that plants artificially induced presented inhibitors until 10 days after the induction, and that an increase in the rate of floral promoter substances was observed only after 15 days. According to Maita et al. [9], the induction of the floral axis is followed by a minimum level of growth promoters $\left(\mathrm{GA}_{3}\right)$ and a maximum level of inhibitors (ABA).

\subsection{The $1997 / 1999$ experiment}

\subsubsection{Season 1 (April/May 1998)}

Comparison between treatments showed that, 156 days after the first application of the products, the plants treated with ACP presented only $5.6 \%$ to $9.1 \%$ of plants with inflorescences and those treated with PBZ presented $21.5 \%$ to $32.1 \%$ of flowering (table IVa). At the same time, in the control, flowering reached $80.5 \%$. Thus, ACP and PBZ significantly inhibited the pineapple flowering. That effect may be a result of no increase in the vegetative growth of the plant, as the products also caused a significant reduction in the ' $\mathrm{D}$ ' leaf length: in the control plants, the 'D' leaf was $81.3 \mathrm{~cm}$ long, while, in the plants treated with ACP3, PBZ1 and PBZ3, the lengths of the 'D' leaves were (69.9, 68.7 and 70.3) cm, respectively. In Australia [7], the same effect was observed on the 'Smooth Cayenne', during the summer production. According to that author, flowering inhibition is related to a decrease in the plant mass, rather than a direct interference of $\mathrm{ACP}$ in the floral differentiation process. 
Table IV.

Effect of growth regulators on the control of natural flowering (\%) of pineapple, cv. Perola, according to two seasons of application (Cruz das Almas, Bahia, Brazil, planting September 1997).

(a) Application in April/May 1998 (season 1)

\begin{tabular}{|c|c|c|c|c|}
\hline \multirow[t]{2}{*}{ Treatment } & \multirow{2}{*}{$\begin{array}{l}\text { Dose } \\
\left(\mathrm{mg} \cdot \mathrm{L}^{-1}\right)\end{array}$} & \multicolumn{3}{|c|}{ Flowering \% observed } \\
\hline & & $\begin{array}{l}108 \mathrm{~d} \\
\text { after the 1st application } \\
\text { of treatments }\end{array}$ & $\begin{array}{l}156 \mathrm{~d} \\
\text { after the 1st application } \\
\text { of treatments }\end{array}$ & $\begin{array}{l}199 \mathrm{~d} \\
\text { after the 1st application } \\
\text { of treatments }\end{array}$ \\
\hline Control (water) & $50 \mathrm{~mL} \cdot$ plant $^{-1}$ & 0 & $80.5 \mathrm{a}$ & $87.0 \mathrm{a}$ \\
\hline ACP & $\begin{array}{c}90 \text { (2 applications) } \\
90 \text { (3 applications) } \\
120\end{array}$ & $\begin{array}{l}0 \\
0 \\
0\end{array}$ & $\begin{array}{l}9.1 \mathrm{c} \\
7.1 \mathrm{c} \\
5.6 \mathrm{c}\end{array}$ & $\begin{array}{l}39.0 \mathrm{bc} \\
34.0 \mathrm{bc} \\
16.5 \mathrm{c}\end{array}$ \\
\hline Paclobutrazole & $\begin{array}{c}240 \text { (2 applications) } \\
240 \text { (3 applications) } \\
320\end{array}$ & $\begin{array}{l}0 \\
0 \\
0\end{array}$ & $\begin{array}{l}21.5 \mathrm{c} \\
32.1 \mathrm{bc} \\
28.0 \mathrm{bc}\end{array}$ & $\begin{array}{l}42.0 \mathrm{abc} \\
45.5 \mathrm{abc} \\
46.5 \mathrm{abc}\end{array}$ \\
\hline Tebuconazole & $\begin{array}{r}60 \\
120\end{array}$ & $\begin{array}{l}0 \\
0\end{array}$ & $\begin{array}{l}59.5 a b \\
68.5 a\end{array}$ & $\begin{array}{l}65.0 \mathrm{ab} \\
74.4 \mathrm{ab}\end{array}$ \\
\hline Propaconazole & 120 & 0 & $67.0 \mathrm{a}$ & $76.5 \mathrm{ab}$ \\
\hline \multicolumn{2}{|c|}{ Growth regulators general averages } & 0 & 41.4 & 55.2 \\
\hline $\begin{array}{l}\text { General } \\
\text { averages }\end{array}$ & $\begin{array}{c}\text { ACP } \\
\text { Paclobutrazole } \\
\text { Tebuconazole }\end{array}$ & $\begin{array}{l}0 \\
0 \\
0\end{array}$ & $\begin{array}{r}7.3 \\
27.2 \\
36.0\end{array}$ & $\begin{array}{l}29.8 \\
44.7 \\
69.8\end{array}$ \\
\hline $\begin{array}{l}\text { Coefficient of va } \\
\text { LSD (Tukey, } 5 \%\end{array}$ & (\%) & - & $\begin{array}{l}40.4 \\
32.6\end{array}$ & $\begin{array}{l}41.3 \\
46.3\end{array}$ \\
\hline \multicolumn{5}{|c|}{ (b) Application in May/June 1998 (season 2) } \\
\hline \multirow[t]{2}{*}{ Treatment } & \multirow{2}{*}{$\begin{array}{c}\text { Dose } \\
\left(\mathrm{mg} \cdot \mathrm{L}^{-1)}\right.\end{array}$} & \multicolumn{3}{|c|}{ Flowering \% observed } \\
\hline & & $\begin{array}{l}80 \mathrm{~d} \\
\text { after the 1st application } \\
\text { of treatments }\end{array}$ & $\begin{array}{l}128 \mathrm{~d} \\
\text { after the 1st application } \\
\text { of treatments }\end{array}$ & $\begin{array}{c}179 \mathrm{~d} \\
\text { after the } 1 \mathrm{st} \text { application } \\
\text { of treatments }\end{array}$ \\
\hline Control (water) & $50 \mathrm{~mL} \cdot$ plant $^{-1}$ & 0 & $48.9 \mathrm{abc}$ & $69.5 \mathrm{a}$ \\
\hline ACP & $\begin{array}{c}90 \text { (2 applications) } \\
90 \text { (3 applications) } \\
120\end{array}$ & $\begin{array}{l}0 \\
0 \\
0\end{array}$ & $\begin{array}{l}10.5 \text { cde } \\
7.1 \text { ed } \\
4.2 \text { e }\end{array}$ & $\begin{array}{l}17.0 \mathrm{dc} \\
10.1 \mathrm{~d} \\
19.1 \mathrm{bcd}\end{array}$ \\
\hline Paclobutrazole & $\begin{array}{c}240 \text { (2 applications) } \\
240 \text { (3 applications) } \\
320\end{array}$ & $\begin{array}{l}0 \\
0 \\
0\end{array}$ & $\begin{array}{l}45.0 \text { abcd } \\
25.1 \text { bcde } \\
22.0 \text { bcde }\end{array}$ & $\begin{array}{l}58.0 \mathrm{abc} \\
60.5 \mathrm{ab} \\
67.0 \mathrm{a}\end{array}$ \\
\hline Tebuconazole & $\begin{array}{r}60 \\
120\end{array}$ & $\begin{array}{l}0 \\
0\end{array}$ & $\begin{array}{l}48.1 a b c \\
66.5 a\end{array}$ & $\begin{array}{l}76.0 \mathrm{a} \\
66.0 \mathrm{a}\end{array}$ \\
\hline Propaconazole & 120 & 0 & $54.0 \mathrm{ab}$ & $68.5 \mathrm{a}$ \\
\hline Growth regulato & eral averages & 0 & 37.5 & 54.2 \\
\hline $\begin{array}{l}\text { General } \\
\text { averages }\end{array}$ & $\begin{array}{c}\text { ACP } \\
\text { Paclobutrazole } \\
\text { Tebuconazole }\end{array}$ & $\begin{array}{l}0 \\
0 \\
0\end{array}$ & $\begin{array}{r}7.9 \\
30.7 \\
57.3\end{array}$ & $\begin{array}{l}15.4 \\
61.8 \\
71.0\end{array}$ \\
\hline $\begin{array}{l}\text { Coefficient of va } \\
\text { LSD (Tukey, } 5 \%\end{array}$ & (\%) & - & $\begin{array}{l}56.3 \\
39.7\end{array}$ & $\begin{array}{l}39.5 \\
43.0\end{array}$ \\
\hline
\end{tabular}

Differences in numbers of days between evaluations, between seasons 1 and 2, are due to the collecting dates of data, which were the same (August 05, September 23 and November 04, 1998) for both seasons.

Values followed by the same letters, in the same column, do not differ (Tukey, $5 \%$ ).

${ }^{1}$ ACP: 2-(3-chlorophenoxy) propionic acid. 
Studying the effect of ACP [(30 to 180) $\mathrm{mg} \cdot \mathrm{L}^{-1}$ ] on 'Smooth Cayenne' flowering, planted in two densities, RebolledoMartínez et al. [10] observed a higher inhibition rate $(18 \%$ flowering) with 46000 plants $\cdot \mathrm{ha}^{-1}$, due, probably, to a higher competition between them, when compared with 33000 plants (24\% flowering). Similar results were obtained in Hawaii [6], and the authors attributed the ACP inhibiting effect, on the contrary, to its auxin-like response in stimulating ethylene production by the stem of the plant. Analyzing ethylene, 1-aminocyclopropane-1carboxilic acid (ACC) and [N-malonyl-(1aminocyclopropane-1-carboxilic acid)] (MACC) contents in the stem tissue of ACPtreated plants, Min observed an increase in the ethylene production and concluded that the mechanisms by which ACP inhibits the pineapple flowering needed further investigation [6].

A $70 \%$ decrease in ethylene production was observed in barley and Brassica napus treated with growth inhibitors, which was accompanied by an increase or maintenance of constant levels of ACC and MACC [11], suggesting the inhibition of the conversion of ACC to ethylene. The inhibiting effects of auxins on floral induction at higher concentrations is not known [6]. It has already been observed that ANA, another synthetic auxin, when used in high concentration, inhibited the pineapple flowering [12, 13], while ACP, at low concentration, had a contrary effect [14].

The other products, tebuconazole (TBZ) at (20 and 40) $\mathrm{mg} \cdot \mathrm{L}^{-1}$ and propaconazole (PPZ) at $40 \mathrm{mg} \cdot \mathrm{L}^{-1}$, even though presenting better inhibiting effects than the control with, respectively, $68.5 \%, 59.5 \%$ and $67.0 \%$ flowering, did not differ from the 80.5\% flowering control (table IVa). The inhibition of natural flowering on 'Smooth Cayenne' pineapple, treated with emersion in (12.5 to 500$) \mathrm{mg} \cdot \mathrm{L}^{-1} \mathrm{TBZ}$ solutions, was observed mainly at higher concentrations [15]. It has already been reported that uniconazole (a product of the same chemical group as TBZ), at (0.5 and 2.5$) \mathrm{mg} \cdot \mathrm{L}^{-1}$ $\left(25 \mathrm{~mL} \cdot\right.$ plant $\left.^{-1}\right)$, not only delayed but also inhibited 'Smooth Cayenne' flowering [6].
This product, when used in the highest concentration, kept the plants in the vegetative stage.

There were no differences between concentrations and number of applications of the treatments, despite the small advantage presented by the ACP (5.6\% flowering) at its higher concentration $\left(4 \times 30 \mathrm{mg} \cdot \mathrm{L}^{-1}\right)$, which means that $94.4 \%$ of the plants did not flower, against 19.5\% inhibition of the control (table IVa). The best result of PBZ (only 21.5\% flowering) was obtained with 2 $\times 120 \mathrm{mg} \cdot \mathrm{L}^{-1}$ (higher concentration per application).

The results obtained 199 days after the first application of treatments in the first season of that experiment were similar to those after 156 days, but a small decrease appeared in the efficiency of the products, mainly in relation to ACP and PBZ (table IVa). Those growth regulators presented, respectively, $16.5 \%$ to $39.0 \%$ and $42.0 \%$ to $46.5 \%$ of flowering. Once again, the ACP was the only product to differ from the control, and, at the highest concentration, it was the most efficient (only 16.5\% of flowering), while $87.0 \%$ of the plants flowered in the control.

An analysis of the averages of the different products used showed that all of them were efficient at reducing flowering (table IVa), but the ACP presented, again, the best effect $(7.3 \%$ and $29.8 \%)$, followed by the PBZ (27.2\% and $44.7 \%$ ), data relative to the last two observations of the April/ May 1998 season.

\subsubsection{Season 2 (May/June 1999)}

As observed in season 1, the ACP was the product which most efficiently decreased the natural flowering of the pineapple: $4.2 \%$ to $10.5 \%$ of flowering, 128 days after the treatment, and $10.1 \%$ to $19.1 \%$ of flowering at the final evaluation; moreover, it is still the only one to significantly differ from the control (table IVb). It was also able to maintain its efficiency for a longer period, even under weather conditions favorable for flowering (table IVb). So, during the period of evaluation, the ACP showed only a small decrease in its efficiency, when compared with season 1. 
Table V.

Temperatures, rainfall and solar radiation of the experimental area (Cruz das Almas, Bahia, Brazil, 1998).

\begin{tabular}{|c|c|c|c|c|c|}
\hline \multirow[t]{2}{*}{ Month } & \multicolumn{3}{|c|}{ Temperature $\left({ }^{\circ} \mathrm{C}\right)$} & \multirow{2}{*}{$\begin{array}{l}\text { Rainfall } \\
(\mathrm{mm})\end{array}$} & \multirow{2}{*}{$\begin{array}{l}\text { Irradiance } \\
\text { (hour) }\end{array}$} \\
\hline & Maximum & Minimum & Average & & \\
\hline April & 34.5 & 20.7 & 25.7 & 128.1 & 239.2 \\
\hline May & 31.8 & 19.0 & 24.0 & 63.7 & 203.3 \\
\hline June & 28.1 & 17.8 & 22.1 & 197.2 & 138.6 \\
\hline July & 29.2 & 17.4 & 22.1 & 112.9 & 175.6 \\
\hline August & 28.4 & 17.1 & 22.3 & 135.4 & 199.3 \\
\hline September & 29.9 & 17.6 & 22.9 & 372.3 & 223.8 \\
\hline October & 36.1 & 18.6 & 24.3 & 57.8 & 243.3 \\
\hline November & 33.6 & 20.5 & 25.5 & 74.8 & 146.8 \\
\hline December & 33.9 & 20.6 & 25.8 & 74.7 & 228.2 \\
\hline
\end{tabular}

Source: agrometeorological station (1st Class), Embrapa Cassava and Fruit Crops, Brazil.

The PBZ was less efficient than ACP, with its flowering rates varying from $22.0 \%$ to $45.0 \%$ at 128 days after the treatments and $58 \%$ to $67 \%$ after 179 days (table $I \mathrm{Vb}$ ). According to those results, it did not differ from the other treatments, including the control. At that time, 179 days after the treatment, the inhibition caused by the PBZ presented a decrease of $31.1 \%$ in relation to that observed after 128 days, which is much higher than that observed in season 1.

During season 2, the only product that affected the vegetative growth of the plant was the PBZ, which presented the shortest 'D' leaf length $(74.0 \mathrm{~cm})$ and lowest dry weight $(8.1 \mathrm{~g})$, against $82.6 \mathrm{~cm}$ and $10.1 \mathrm{~g}$ of the control.

The ACP significantly decreased flowering in the pineapples 'Smooth Cayenne' and 'Queen', the highest concentrations $\left(3 \times 30 \mathrm{mg} \cdot \mathrm{L}^{-1}\right.$ and $\left.4 \times 30 \mathrm{mg} \cdot \mathrm{L}^{-1}\right)$ being most efficient (only $1.0 \%$ to $23.0 \%$ of flowering) $[10,16,17]$. In some cases, authors also observed phytotoxic effects of ACP on the plants, even death, in general, with very high concentrations. The ACP stimulates ethylene production by the pineapple plant, but the mechanism is not known [6]. In relation to the PBZ, it was observed that ethylene production was significantly reduced, and also the ACCOase (ethylene forming enzyme) activity, which could be one of the reasons for the delaying of the flower differentiation caused by that product [6].

\subsubsection{Season 1 vs. season 2}

In the first evaluation (August 05, 1998), 108 days after the treatment in season 1 and 80 days after in season 2 , all the plants did not produce flowers (table IVa), which means that up to 40 days before the above cited date, the floral initiation at the apical meristem had not taken place, despite the decrease in the temperature and irradiance in June (table $V$ ).

Based on a combined analysis of the results obtained in both seasons, all the treatments presented the same pattern of performance, corroborating the ACP and $\mathrm{PBZ}$ as the most efficient flowering inhibitors (table $V$ ), differing significantly from the others, the former being superior, with only $7.3 \%$ and $22.6 \%$ of average flowering.

The month of application did not enhance, in a significant manner, the effectiveness of the growth regulators. The general averages for flowering were $37.9 \%$ and $52.6 \%$ (season 1), and $33.1 \%$ and $51.2 \%$ (season 2), referring, respectively, to the second and the last observations which, in this case, did not differ statistically from each other. 
Table VI.

Effects of growth regulators on the control of natural flowering (\%) of pineapple, cv. 'Perola', regarding a combined analysis of two seasons of application (April/May 1998 and May/June 1998). The evaluations were done on September 23, 1998 and November 04, 1998, for the two seasons (Cruz das Almas, Bahia, Brazil, planting September 1997).

\begin{tabular}{|c|c|c|c|c|}
\hline \multirow[t]{2}{*}{ Treatment } & \multirow{2}{*}{$\begin{array}{c}\text { Dose } \\
\left(\mathrm{mg} \cdot \mathrm{L}^{-1}\right)\end{array}$} & \multicolumn{2}{|c|}{ Flowering (\%) average } & \multirow[t]{2}{*}{ General average (\%) } \\
\hline & & September 23 & November 4 & \\
\hline Control (water) & $50 \mathrm{~mL} \cdot$ plant $^{-1}$ & $64.7 \mathrm{a}$ & $78.3 \mathrm{a}$ & 71.5 \\
\hline \multirow[t]{3}{*}{$\mathrm{ACP}^{1}$} & 90 (2 applications) & $9.8 \mathrm{~cd}$ & $28.0 \mathrm{bcd}$ & - \\
\hline & 90 (3 applications) & $7.1 \mathrm{~d}$ & $32.1 \mathrm{~cd}$ & - \\
\hline & 120 & $4.9 \mathrm{~d}$ & $17.8 d$ & - \\
\hline ACP average & - & 7.3 & 22.6 & 14.9 \\
\hline \multirow[t]{3}{*}{ Paclobutrazole } & 240 (2 applications) & $33.3 \mathrm{bc}$ & $50.0 \mathrm{abc}$ & - \\
\hline & 240 (3 applications) & $28.6 \mathrm{~cd}$ & $53.0 \mathrm{ab}$ & - \\
\hline & 320 & $25.0 \mathrm{~cd}$ & $56.8 \mathrm{ab}$ & - \\
\hline Paclobutrazol average & - & 29.0 & 53.3 & 41.1 \\
\hline \multirow[t]{2}{*}{ Tebuconazole } & 60 & $53.8 \mathrm{ab}$ & $70.5 \mathrm{a}$ & - \\
\hline & 120 & $67.5 \mathrm{a}$ & $70.3 \mathrm{a}$ & - \\
\hline Tebuconazole average & - & 60.6 & 70.4 & 65.5 \\
\hline Propaconazole & 120 & $60.5 \mathrm{a}$ & $72.5 \mathrm{a}$ & 66.5 \\
\hline General average & & 32.2 & 49.0 & 40.6 \\
\hline LSD (Tukey 5\%) & & 24.9 & 30.6 & - \\
\hline Coefficient of variation (\%) & & 48.0 & 40.4 & - \\
\hline
\end{tabular}

Values followed by the same letters, in the same column, do not differ (Tukey, 5\%).

${ }^{1}$ ACP: 2-(3-chlorophenoxy) propionic acid.

As previously mentioned, natural flowering in pineapple is very inconvenient, because the fruit production is scattered, increasing harvesting costs. Since the commercial cultivation of pineapple depends on the artificial induction of flowering, harvesting should be planned for seasons when fruit supply is lower and prices are better. Thus, inhibiting natural flowering or delaying harvesting, even for a short period of time, becomes of great importance, due to the increase in fruit prices, and also in the growers' income. And that is exactly one of the main objectives of this kind of research, since natural flowering control by the traditional cultural practices (planting material, fertilization, irrigation) has not proved to be consistently efficient.

\section{Conclusion}

ACP and PBZ were capable of inhibiting and delaying the floral initiation of the 'Perola' pineapple; the best product concentrations were between (90 and 240) $\mathrm{mg} \cdot \mathrm{L}^{-1}$, split into two and three equal applications, during April and May.

The other growth regulators (TBZ, PPZ, $\mathrm{GA}_{3}$ ) did not have an effect on flowering.

The observed variations in the effects and efficiency of the products, in relation to flowering inhibition, indicate the need for validating the best treatments under natural (environmental) and cultural conditions in the pineapple producing regions in the 
country, and also with other cultivars, mainly the 'Smooth Cayenne'.

ACP and PBZ can be useful for studying the physiology of the mechanisms of the floral initiation on pineapple.

\section{Acknowledgements}

We are grateful to Dr. Ranulfo Correa Caldas (Embrapa Cassava and Fruit Crops) for his help with statistical analyses and comments, and also to the Northeast Brazilian Bank/BNB, for the financial support of this study.

\section{References}

[1] Barbosa N.M.L., Cunha G.A.P. da, Reinhardt H.D., Barros P.G., Controle da floração natural do abacaxizeiro 'Pérola' com uréia e reguladores de crescimento, no Reconcavo Baiano, Rev. Bras. Frutic. 20 (3) (1998) 359-366.

[2] Hamza A.M., Helaly M.N.M., Interaction between chlormequat (CCC) and gibberellin $\left(\mathrm{GA}_{3}\right)$ on growth, flowering and mineral constituents of some ornamental plants, Acta Hortic. 137 (1983) 197-210.

[3] Mekers O., De Proft M., Prevention of unwanted flowering of ornamental Bromeliaceae by growth regulating chemicals, Acta Hortic. 137 (1983) 217-224.

[4] Cunha G.A.P. da, Teste preliminar sobre o controle da floração natural do abacaxizeiro, Rev. Bras. Frutic. 11 (3) (1989) 59-62.

[5] Min X.J., Bartholomew D.P., Effects of growth regulators on ethylene production and floral initiation of pineapple, Acta Hortic. 334 (1993) 101-112.

[6] Min X.J., Physiological effects of environmental factors and growth regulators on floral initiation and development of pineapple [Ananas comosus (L.) Merr.], Univ. Hawaii, Thesis, Honolulu, USA, 1995, 111 p.
[7] Scott C.H., The effect of two plant growth regulators on the inhibition of precocious fruiting in pineapple, Acta Hortic. 334 (1993) 77-82.

[8] Das Biswas S., Dhua R.S., Mitra S.K., Bose T.K., Physiological studies on flowering of pineapple in response to chemicals and environment, Acta Hortic. 137 (1983) $231-$ 242.

[9] Maita A., Martnez T., Perez S., Nogueira J., Study on the floral induction, growth and development of pineapple, in: Subradrabundhu S., Chairidchai P., Third Int. Pineapple Symp., Abstr., ISHS, Pattaya, Thailand, 1998 , p. 20.

[10] Rebolledo-Martínez A., Uriza-Ávila D., Aguirre-Gutiérez L., Inhibición de la floración de la piña con diferentes dosis de Fruitone CPA a dos densidades de siembra, Acta Hortic. 425 (1997) 347-354

[11] Grossmann K., Hauser C., Sauerbrey H., Fritsch H., Schmitd O., Jung J., Plant growth retardant as inhibitors of ethylene production, J. Plant Physiol. 134 (1989) 538-543.

[12] Gowing D.P., An hypothesis of the role of naphthaleneacetic acid in the flower induction of pineapple, Am. J. Bot. 43 (1956) 411-418.

[13] Millar-Watt D., Control of natural flowering in Smooth Cayenne pineapple, Ananas comosus (L.) Merr., Subtropica 2 (1981) 17-19.

[14] Gowing, D.P., Leeper R.W., Studies on the relation of chemical structure to plant growth-regulator activity in the pineapple plant. I. Substituted phenyl and phenoxyalkylcarboxylic acids, Bot. Gaz. 121 (160) 143-151.

[15] Taniguchi G., Effect of tebuconazole on natural flower induction, Pineapple News 6 (1999) 11

[16] Rebolledo-Martínez A., Uriza-Avila D.E., Rebolledo M.L., Rates of Fruitone CPA in different applications number during day versus night to flowering inhibition in pineapple, Acta Hortic. 529 (2000) 185-190.

[17] Rabie E.C., Tustin H.A., Wesson K.T., Inhibition of natural flowering occurring during the winter months in 'Queen' pineapple in Kwazulu Natal, South Africa, Acta Hortic. 529 (2000) 175-184. 


\section{Floración natural en piña: inhibición mediante reguladores de crecimiento.}

Resumen - Introducción. La floración natural es un obstáculo para el manejo de la producción de piña. Este fenómeno causa pérdidas considerables y crecientes a escala internacional. El objetivo de este trabajo consistió en determinar, en distintas épocas del año, el papel de sustancias que inhiben el crecimiento vegetativo de la planta para impedir, reducir o retrasar la floración natural de piña de la variedad 'Perola' la más cultivada en Brasil. Material y métodos. Se siguieron dos ensayos en parcela experimental en Cruz das Almas, Bahia (Brasil), durante los años 1996 a 1999. Se probaron diferentes sustancias de crecimiento con distintas concentraciones: el ácido 2-(3-clorofenoxi) propiónico (ACP) a (45, 90 y 120) $\mathrm{mg} \cdot \mathrm{L}^{-1}$, el paclobutrazol (PBZ) a $\left(77,4,155,8\right.$ y 320) $\mathrm{mg} \cdot \mathrm{L}^{-1}$, el cloruro de mepiquat (CM) a $\left(60\right.$ y 120) $\mathrm{mg} \cdot \mathrm{L}^{-1}$, el ácido giberélico $\left(\mathrm{GA}_{3}\right)$ a $(30 \mathrm{y} 60) \mathrm{mg} \cdot \mathrm{L}^{-1}$, el tebuconazol (TBZ) a $\left(60\right.$ y 120) $\mathrm{mg} \cdot \mathrm{L}^{-1}$ y el propaconazol (PPZ) a $120 \mathrm{mg} \cdot \mathrm{L}^{-1}$. Los tratamientos se aplicaron en dos, tres o cuatro dosis iguales, cada 15 días, de 7.00 a 9.00 h de la mañana y de abril a julio (período crítico para las floraciones naturales en la región del ensayo). Resultados y discusión. Los resultados obtenidos mostraron que el ACP y el PBZ son capaces de inhibir, reducir y retrasar la floración natural de piña con concentraciones comprendidas entre (90 y 240) $\mathrm{mg} \cdot \mathrm{L}^{-1}$. Los mejores resultados se obtuvieron cuando los reguladores de crecimiento se aplicaban durante los meses de abril y mayo. Los otros productos probados no tuvieron efectos sobre la floración natural de la piña. Conclusión. Los efectos y la eficacia variables de los reguladores de crecimiento empleados hacen que haya que adaptar los tratamientos a las distintas condiciones medioambientales y de cultivo. Los reguladores de crecimiento ACP y PBZ podrían ser útiles para estudios fisiológicos sobre los mecanismos de la iniciación floral en la piña.

Brasil / Ananas comosus / floración / precocidad / inhibidores del crecimiento / triazoles

To access this journal online: www.edpsciences.org 